\title{
DEVELOPMENT OF EUROPEAN CONSCIOUSNESS IN ERASMUS STUDENTS ${ }^{4}$
}

\author{
Sevda MutLu \\ smutlu75@gmail.com
}

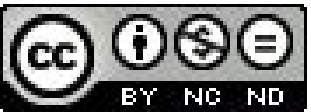

\begin{abstract}
This research is the content analysis of 502 Erasmus students' experiences published in the website www.20erasmus.eu. One of the main purposes of the Erasmus Student Exchange Program is to maintain a cross-cultural dialogue through student activity, to remove prejudices and thus to strengthen interaction and join EU citizens under such concepts as "European Consciousness" and "Being European". The purpose of this study is to determine how successful the Erasmus Student Exchange Program is through the shared Erasmus experiences of the participating students.

In conclusion, in this research, it is observed that the students talked highly positively about the Erasmus experience. The students described this process as enjoyable and productive. It could be argued that the Erasmus experience contributed to students' "individual development" rather than "academic development". It could also be maintained that one of the key purposes of the Erasmus exchange program is to remove prejudices by maintaining student mobility and cross-cultural dialogue and to unite societies under the European Consciousness and European People understanding via strengthening interactions between EU member citizens. Data collected in this research present evidence that the Erasmus programme has reached this aim.
\end{abstract}

Key words: EU, European Consciousness, Erasmus Student, Academic Experience, Personal Experience.

\section{INTRODUCTION}

Student activity is an increasing phenomenon not only in Europe, but also in other parts of the world. "Internationalization in higher education is an inevitable result of the globalized and knowledge-based economy of the 21st century" (Altbach, Teichler 2001). Although European Union members have common political and economic principles, due to the differences in their cultural and educational policies, they had to create a common educational policy and strategy. For this reason, "Education in a single Europe" had to be supported. (Brock, Tulasiewicz 1999, p. x). Therefore, one of the latest and significant integration policies of the EU has been the Erasmus Student Exchange program. In order to guarantee the safety of the EU's future and to provide young people with education, with the process of The European Higher Education Bologna, education has been reshaped. "Both the Bologna Process and the general globalization trend seem to support student mobility in some respects but to set new barriers in other respects" (Rivza, Teichler 2007, p. 61). What makes Erasmus student program more significant in comparison with other student activities is that, the program is

4 Some data from this study have been presented as a paper in the ERCON 2010, Erasmus Coordinators Conference Vienna. 
completely financed by the EU and it is short. The number of students benefiting from this program is increasing every day. For this reason, more and more students benefit from it and will continue to do so.

The Erasmus program is one of the most important tools the EU uses to create a "European consciousness". "Since 1988, the development of the »European dimension « in education in order to reinforce the European identity/citizenship, to increase awareness of common socio-political issues and to enhance knowledge of the historical and cultural aspects of Europe has become an EU leitmotif. The educational community welcomed this approach that was closer to educational ideals than a purely economic rationale. The White Paper on the »Learning Society« acknowledged that »education and training will increasingly become the main vehicle for self-awareness, belonging, advancement and self-fulfillment « and stressed that "education lays the foundation of awareness and European citizenship «" (Papatsiba 2005, s. 176). The Erasmus student exchange program aims at internalizing Europeans within a "European Consciousness" (Byram 2001, p. 108).

"Academic exchange and internationalization are viewed as among the »success stories « of innovation in 20th century higher education. At the end of the century and the beginning of the new millennium, there is widespread agreement that internationalization is a key element of the future of higher education. Some experts, for example, even claim that SOCRATES/ERASMUS has been the most successful single component of EU policy" (Altbach, Teichler 2001, p. 10). According to Teichler, the Erasmus program achieves an international success: 1 . EU policy was successful in moving cross border student mobility in Europe from an exceptional phenomenon, for which the students were largely responsible themselves, to a phenomenon the success of which became a concern for the higher education institutions. 2. ERASMUS succeeded (to some extent) in counterbalancing the imbalances of intra-European exchange. 3. ERASMUS clearly encouraged cooperation in curricular matters. 4. ERASMUS promoted European cooperation and the 'European dimension' of higher education in a way that European activities increased in quantity and weight, without contradicting internationalization in any principal respect. ERASMUS, thus, speeded up internationalization of European institutions of higher education (1999, p. 12). At the same time we are aware that not only European-level policies such as the Erasmus programme affect national policies" (Huisman 2004, p.2).

The Erasmus program has been gaining the attention of researchers recently, due to its international success and its effect on the union of the EU (the most important effect being the dialogue between cultures). "the Erasmus program is a good opportunity to collect exciting data, because it rings together people from different countries, who have now become ubiquitous in institutions of higher education. As Erasmus "groups « are constantly in nascendi (students never stay more than 9 months in the host country), the phenomenon allows various societal and intercultural issues to be looked at such as the creation of relationships, adaptation to host countries, management of identity, the development of intercultural competence. In other words, it is one of the best laboratories available for researchers" (Devrin 1984, 170). This research has been done in the mentioned laboratory. The experiences of those Erasmus students which can be found in the web site: www.20Erasmus.eu 
have been analyzed contextually. The study aims to understand whether Erasmus students place particular emphasis on their academic developments or personal developments in evaluating their Erasmus experiences. Therefore, Erasmus experiences are going to be analyzed using two principal categories, "academic development" and "personal development", and the distribution of word frequencies associated with each will be examined using content analysis methods.

\section{MATERIAL AND METHODS}

In this research, the content analysis method has been used. 502 students who have had an Erasmus experience have shared these in the www.20Erasmus.eu web site. This study aims to identify the most frequently mentioned concepts in response to the Erasmus experience-related questions "Did you grow-up? Was this experience useful for your life and for your career? Did you feel like home away from home? Did Erasmus change your life? Do you miss that time?" published in the website www.20Erasmus. eu, the context (positive/negative) and the attitudes towards Erasmus program via content analysis. These experiences have each been scanned and analyzed. The 502 Erasmus experiences were conducted via Simple Concordance 4.0.7. program. Thus, the total word number and word frequency could be presented in tables.

"Content analysis is a highly flexible research method that has been widely used in library and information science (LIS) studies with varying research goals and objectives. Based on a basic communications model of sender/ message/ receiver, initially researchers emphasized making inferences based on quantified analysis of recurring, easily identifiable aspects of text content, sometimes referred to as manifest content. Since then, researchers in many fields, including anthropology, library and information studies (LIS), management, political science, psychology, and sociology, have used content analysis. In the process, they have adapted content analysis to suit the unique needs of their research questions and strategies and have developed a cluster of techniques and approaches for analyzing text grouped under the broad term of textual analysis" (White, Marsh 2006, 22-23).

\section{DATA}

The text which underwent content analysis comprises 100443 words. These were written in 8466 different words. The longest sentence contains 2.254 words. The shortest sentence contains 2 words.

\section{HYPOTHESES}

1. The Erasmus experience is a highly beneficial period for students. It serves to develop the students personallly, rather than academically.

2. The Erasmus experience helps the students to look within themselves and understand themselves better.

3. The Erasmus experience gives the students a chance to establish cross-cultural dialogues and thus forms a European Consciousness in students, who are alienated from their prejudices. 


\section{CONTENT ANALYSIS OF ERASMUS EXPERIENCES, TABLES AND COMMENTS}

The country distribution of the students sharing Erasmus experiences reveals that the highest rate of contribution belongs to Italy and Spain, France, Poland and Portugal.

Tab. 1. Distribution of Erasmus Experiences By Country

\begin{tabular}{|c|c|c|c|c|c|}
\hline Country name & $\begin{array}{c}\text { Number of Eras- } \\
\text { mus Experience }\end{array}$ & $\%$ & Country name & $\begin{array}{c}\text { Number of Eras- } \\
\text { mus Experience }\end{array}$ & $\%$ \\
\hline Italy & 109 & 21.58 & UK & 13 & 2.57 \\
\hline Spain & 59 & 11.68 & Czech Republic & 10 & 1.98 \\
\hline France & 35 & 6.93 & Slovakia & 8 & 1.58 \\
\hline Poland & 34 & 6.73 & Hungary & 8 & 1.58 \\
\hline Portugal & 34 & 6.73 & Bulgaria & 7 & 1.39 \\
\hline Belgium & 28 & 5.54 & Lithuania & 5 & 0.99 \\
\hline Germany & 26 & 5.15 & Estonia & 4 & 0.79 \\
\hline Romania & 22 & 4.36 & Austria & 4 & 0.79 \\
\hline Sweden & 21 & 4.16 & Latvia & 3 & 0.59 \\
\hline Netherland & 19 & 3.76 & Ireland & 3 & 0.59 \\
\hline Finland & 17 & 3.37 & Slovenia & 3 & 0.59 \\
\hline Greece & 15 & 2.97 & Denmark & 2 & 0.40 \\
\hline Turkey & 14 & 2.77 & Norway & 2 & 0.40 \\
\hline \multicolumn{2}{|l|}{ Sum } & 502 & 100.00 \\
\hline
\end{tabular}

Source: prepared by author.

\section{CONTENT ANALYSIS OF ERASMUS EXPERIENCE TITLES}

Data: The Erasmus Experience titles text which underwent content analysis comprises 2562 words. These were written in 495 different words.

Tab. 2. The frequency distribution of the words used in Erasmus experience titles

\begin{tabular}{|c|c|c|c|}
\hline Range & Word & Frequency & $\%$ \\
\hline 1 & Discover & 137 & 31.07 \\
\hline 2 & Life & 70 & 15.87 \\
\hline 3 & Love & 58 & 13.15 \\
\hline 4 & Dream & 44 & 9.98 \\
\hline 5 & Touch & 38 & 8.62 \\
\hline 6 & Erasmus & 29 & 6.58 \\
\hline 7 & World & 25 & 5.67 \\
\hline 8 & Europe & 17 & 3.85 \\
\hline 9 & Experience & 13 & 2.95 \\
\hline 10 & Friend & 10 & 2.27 \\
\hline & Sum & 441 & 100.00 \\
\hline
\end{tabular}

Source: prepared by author. 
According to Table 2, the total of the words ranking in top 10 is 441 . The fact that the exclamation mark (!) was used 232 times in the titles is an indication of the excitement with which students talk about their experiences. Students used the concept "discover" most frequently in the experience title. 23 students used the expression "we discovered", while 114 used the expression "I discovered". Thus, one can infer that the Erasmus experience is a relatively individualistic and personal experience.

The usage contexts of the concepts in the table are as follows:

\section{Discover}

It was also observed that the students used the word "discover" most frequently in relation to "themselves" and "life".

a) The students emphasized the following in their discoveries related to themselves:

I discovered --------- $\rightarrow$ myself, my limits, a new side of me, myself differently, a new me, my identity, my reality, I discovered myself being happy, who I really am, another me

b) The students emphasized the following in their discoveries related to life:

I discovered --------- $\rightarrow$ a new way of life, So much about life, what life is, How good life can be, lovely lifestyle, a new life, a new way of life, the meaning of life, easy life, how much life can, different ways of life, Erasmus life.

c) Other subjects and areas discovered by students are as follows:

I discovered --------- $\rightarrow$ Multiculturality, international, Europe, a wonderful place, true emotions, home away from home, the world, new world, others, paradise, similarities, dreams, magic of cultures, sing Language, universe, diversity, rainbow world joy, a great friendship, many new people, so many things, love, hundreds of different worlds, the heaven, diversity, happiness, European essence, pure and unlimited freedom, what is the mix of nations, each other, other world.

At this point, it could be argued that students' range of exploration is highly diverse.

\section{Life}

The second most frequently used concept in the experience title is "life". The word "life" is mostly used together with "discovery", which is also mentioned above.

Apart from this, an analysis of the meaning and context in which life was used shows that; I had the time of my life, I had the best time/year of my life, I had change my life, I had Experience a new life, I started a new life, I did the best decision of my life, I smelled/ my life, I touched real life, I widen my life, We saw the heaven of life.

As can be seen, students used the concept life in both concrete and positive sense.

\section{Love}

An analysis of the concept love shows that; Every single minute, this time, Erasmus sharing cultures, Eastern Europe, Europe, to be Erasmus person, my Erasmus time, every single day, host country. 


\section{Dream}

An analysis of the concept dream shows the following:

It was also observed that the students use the concept of dream in two senses;

a) That they realized their dreams through the Erasmus experience;

b) That their Erasmus experience was like a dream and they had a dream during this process.

Both senses encompass a positive meaning and a feeling of excitement.

\section{Touch}

The concept of touched is as follows:

I/ we touched.......Sky, Europea, my dreams, time, endless, happiness, my life, my soul, dream, the paradise.

\section{Erasmus}

In relation to the use of the Erasmus concept: The students mentioned that they felt, discovered and loved Erasmus.

\section{World}

As for the concept "world": Students used the concept "world" in two senses;

1. The concrete and physical sense: to see new places in the world and discover the variety and colour in the world.

2. The abstract sense: to see different worlds, to explore their own world.

\section{Europe}

The use of the concept "Europe" is as follows: The students stated that they explored, felt, loved and lived the spirit of, Europe and the meaning of EU. It is interesting that the students stated having discovered Europe and living the European spirit although the majority were of European origin. It can be seen that the Erasmus programme helped develop an awareness of Europe and Europeans.

\section{Experience}

The students used the experience concept with highly positive adjectives: They described the experience concept with the adjectives "great, wonderful, beautiful, exciting, changing". Also, they expressed that they experienced a new and different lifestyle and future.

\section{Friend}

The concept of friends: The students said that they met friends from different parts of the world and built friendships that would last forever. The contextual analysis of the experience titles used by the students, shows that this experience process has had very positive effects on them. We may categorize these positive effects into three:

1. Discovering themselves,

2. Discovering different cultures and

3. Gaining a European consciousness. 


\section{CONTENT ANALYSIS OF ERASMUS EXPERIENCES}

The text which underwent content analysis is comprised of 100443 words. These were written in 8466 different words. The longest sentence contains 2.254 words. The shortest sentence contains 2 words.

Tab. 3. The frequency distribution of the words used in Erasmus experiences

\begin{tabular}{|c|c|c|c|}
\hline Range & Word & Frequency & $\%$ \\
\hline 1 & Erasmus & 1007 & 18.6 \\
\hline 2 & People & 631 & 11.6 \\
\hline 3 & Life & 599 & 11.1 \\
\hline 4 & Friends & 462 & 8.5 \\
\hline 5 & Experience & 450 & 8.3 \\
\hline 6 & Time & 438 & 8.1 \\
\hline 7 & Student & 391 & 7.2 \\
\hline 8 & New & 364 & 6.7 \\
\hline 9 & Different & 284 & 5.3 \\
\hline 10 & Other & 253 & 4.7 \\
\hline 11 & World & 218 & 4.0 \\
\hline 12 & University & 165 & 3.0 \\
\hline 13 & Language & 157 & 2.9 \\
\hline & Sum & 5419 & 100.0 \\
\hline
\end{tabular}

Source: prepared by author.

According to the table, the sum of the words in the 13 most frequently used words is 5419. While 156 students used the expression "My Erasmus", 17 students used "our Erasmus" and 5 students used "your Erasmus".

\section{Erasmus}

The "Erasmus" concept was most frequently used in the Erasmus experiences. It is evident that the students have created an "Erasmus terminology". This terminology is composed of naturally emerging concepts formed as a result of the students' experiences. They can express many things that they feel and they understand each other by means of these concepts. 
Tab. 4. Erasmus Terminology

\begin{tabular}{|c|c|c|c|c|c|}
\hline Word & Frequency & $\%$ & Word & Frequency & $\%$ \\
\hline Erasmus students & 129 & 31.23 & Erasmus studies & 3 & 0.73 \\
\hline Erasmus experience & 78 & 18.89 & Erasmus language & 3 & 0.73 \\
\hline Erasmus year & 30 & 7.26 & Erasmus days & 3 & 0.73 \\
\hline Erasmus friend & 24 & 5.81 & Erasmus network & 2 & 0.48 \\
\hline Erasmus programme & 21 & 5.08 & Erasmus money & 2 & 0.48 \\
\hline Erasmus life & 21 & 5.08 & Erasmus dream & 2 & 0.48 \\
\hline Erasmus people & 14 & 3.39 & Erasmus community & 2 & 0.48 \\
\hline Erasmus time & 13 & 3.15 & Erasmus night & 1 & 0.24 \\
\hline Erasmus family & 9 & 2.18 & Erasmus generation & 1 & 0.24 \\
\hline Erasmus parties & 7 & 1.69 & Erasmus nick & 1 & 0.24 \\
\hline Erasmus spirit & 7 & 1.69 & Erasmus nationality & 1 & 0.24 \\
\hline Erasmus group Erasmus & 7 & 1.69 & Erasmus story & 1 & 0.24 \\
\hline period & 7 & 1.69 & Erasmus world & 1 & 0.24 \\
\hline Erasmus semester & 4 & 0.97 & Erasmus gift & 1 & 0.24 \\
\hline Erasmus scholarship & 4 & 0.97 & Erasmus girl & 1 & 0.24 \\
\hline Erasmus bar & 4 & 0.97 & Erasmus association & 1 & 0.24 \\
\hline Erasmus months & 4 & 0.97 & Erasmus trip & 1 & 0.24 \\
\hline Erasmus section & 3 & 0.73 & & & \\
\hline & & & Sun & 413 & 100,00 \\
\hline
\end{tabular}

Source: prepared by author.

One of the most used and prominent concepts is the Erasmus Spirit. Erasmus spirit does not have a concise definition; however, what Erasmus spirit encompasses can be listed on the basis of data collected via content analysis. The Erasmus spirit includes discovering primarily oneself, new places, new tastes; making new friends, having fun in Erasmus parties, entertainment and travelling. The Erasmus spirit does not contain prejudices, isolation, national, ethnic and religious identities.

As expressed by a student (Karolina from Wroclaw: "We were like a family" 2006):

It had no meaning whether you were from Poland, Turkey or Greece

It had no meaning whether you were a Catholic, Muslim or Orthodox

It had no meaning whether you liked heavy metal or techno

It had no meaning whether you were straight or gay

It had no meaning whether you liked cats or dogs

Erasmus concept has been most used with these adjectives and this frequently: Great Erasmus (251), first Erasmus (250), very Erasmus (248), best Erasmus (245), love Erasmus (148), wonderful Erasmus (93), beautiful Erasmus (86), fun Erasmus (84), nice Erasmus (84), better Erasmus (81), enjoy Erasmus (72), thanks Erasmus (67), perfect Erasmus (37), funny Erasmus (35), bad Erasmus (32)

Some notable expressions used in Erasmus are as follows: Some significant expressions taken from the experiences of students are as follows:

- "Erasmus life it's unreal"

- "It is unique"

- "Erasmus in my soul"

- "My Erasmus was AMAZING" 
- "Erasmus is a special time"

- "Be Erasmus!!!!"

- "Erasmus generation is the future of Europe and we will keep it living"

- "ERASMUS spirits is still running around the World"

- "There is a before and an after Erasmus in my life".

- "My Erasmus was breathtaking"

- "Erasmus as a new beginning"

- "I didn't expect my Erasmus to turn out such an international experience.

- "Have you ever met somebody with a bad experience on Erasmus programme? Stop searching you will not find it".

This is how the Erasmus concept was used by the students:

1. The majority of the students stated that Erasmus changed them and their lives to a great extent.

2. They evaluated the process as joyous, enjoyable and productive.

3. The number of people expressing gratitude for the Erasmus is unignorable. In addition, they expressed wishes like "God save Erasmus" and "Long live Erasmus".

4. Most of the students expressed that they explored and found about themselves through Erasmus.

5. They stated that talking about and describing Erasmus is not easy and that people lacking this experience would have difficulty understanding this.

6. Erasmus is highly recommended for everyone. They even describe the process as indescribable and a must for everyone. Some even have recommendations like "Do not attend Erasmus, live Erasmus!".

7. The number of students who state that they will never forget those days is also high.

8. Most of the students want to return back to the Erasmus period.

9. They think that Erasmus is not "a waste of time".

10. They long for the Erasmus period and friends.

11. Some evaluate Erasmus as a chance.

12. Students state that Erasmus never ends. It could be argued that its effect continues despite having ended as an action.

13. Five students stated they found their husbands and five stated they found their wives in this experience.

14. Many students think that Erasmus has created a new culture.

15. They evaluated Erasmus as an important period in their lives.

16. A student pointed to similarities between Plato's metaphor of cave and Erasmus.

17. There are even some who say "I wish I could stay as an Erasmus student forever".

18. The number of students saying "Erasmus was the best decision in my life" is quite high.

19. The students stated that they became more positive thanks to Erasmus. Again, the number of people wishing to participate in the Erasmus program is quite high. 
20. There are a few students who separate their lives into two periods: Pre-Erasmus and Post-Erasmus.

21. There are many students who think that Erasmus put an end to their routine life style and made them more European.

22. There are only a few students who think that the Erasmus funding was insufficient.

23. There are even people who identify themselves with Erasmus and go so far as to say: "We were Erasmus".

24. Two students have coded Erasmus exactly as follows:

Petra from Slovakia, "We want it back", 2006: DJ Nash, from Madrid "I upgraded myself", 2002:

E - eternal friendships

$\mathrm{R}$ - romance

A -anything was possible

$\mathrm{Z}$ - zest for travelling

$\mathrm{M}$ - more than a student exchange programme

$\mathrm{U}$ - unbelievable experiences

$\mathrm{S}$ - socializing
European

Romantic/Responsible

Ambassador

Strenghtening

Mankind

Union

Smoothly

\section{People}

The second most frequently used word is People.

It can be observed that expressions related to meeting people from new and different cultures, and the expressions "there aren't people categories", "unite people in diversity", "Erasmus people were/are unique" are frequently used. The students also pointed to the fact that people are very similar to each other and could be close to each other despite coming from distant places and mentioned the shared beauties. It can also be seen that the adjectives used in relation to the concept of people have highly positive connotations: wonderful, special, fantastic, important, good, great, enjoy, the best, the nicest, the greatest, happy, friendly people.

The description of a new person type is evident: Erasmus people. There are also positive opinions of the local people.

Here, there is no discrimination and otherisation in the use of "other people".

Samples of referring to other people are listed below:

1. A student mentioned $\mathrm{s} /$ he has become more open to other people

2. A student mentioned sharing the same corridor with " 12 other people".

3. That Erasmus taught a lot about themselves and other people.

4. That they were like a family, and the others' problems were also yours.

5. That they met other people from a different culture

6. That it opened the door to other people

7. That they cooperated with other people

8. That they were organized with other people

As can be seen, an otherisation is not present here. On the contrary, students emphasized forming a unity despite the differences. 
It was observed that the concept of people was used negatively in only three places.

1. Bad people: A student mentioned her worries about being stalked by a male stranger she met in the tram while looking for the place she was supposed to stay and stated that it was difficult for her to save herself from the man.

2. Shallow people: A student mentioned the presence of some shallow people who became drunk in parties.

3. A French student (going to Italy) conceived of Erasmus as a waste of great amounts of money and thought that young people used this money for alcohol and drugs. He had witnessed that the students used most of their time consuming alcohol and drugs in Erasmus bars.

The main opinion of the students is:

1. There aren't people categories

2. Unite people in diversity

3. Erasmus people were/are unique. According to these statements, we can say that Erasmus students have won European consciousness.

\section{Life}

The third most frequently used concept is Life.

The fact that the concept "my life" was used 269 times indicates that the students told this experience from the perspective of their own lives. The most frequent use of the "life" concept is "the best day/time/ year/ period / part/decision of my life". Another frequently mentioned thing was that the Erasmus experience changed their lives. The concept of life often is used the following attributes: new life, different life, great life, magic life, perfect life, multinational life, amazing life, second life, social life, university life. A negative use of the life concept was not observed.

Two new uses of the life concept were noted:

- Erasmus life $=$ The period spent as an Erasmus student in the host country.

- European Life = Making friends from different European societies, travelling and experiencing European life style.

\section{Friend}

They made friends from different cultures and countries and built good friendships and relationships. Shared activities like travelling with friends, going to the cinema and theatre, etc. were mentioned frequently. The majority of the students talked about the loneliness and the things they suffered from in the first days; however also mentioned that they overcame many difficulties soon by making new friends and built firm relationships. The number of people visiting their friends after Erasmus is unignorable. It is evident that the discovery of different places and cultures continues with friend visits after Erasmus. The concept of friend often is used the following attributes: new friend, best friend, good friend, great friend, foreign friend, special friend, nice friend, crazy friend, amazing friend, adorable friend, extraordinary friend, wonderful friend, lifelong friend, beautiful friend, closer friend, international friends, true friendships, strong friendship, universities friendship, unforgettable friendships, colorful friendship. 
In this study, it has been determined that the students talk about their friendships very positively and very frequently. The texts related to the experiences of the students show that their friendships are not transitory, but temporary. The number of those who visit their friends' country after the Erasmus program is not low at all. These kinds of visits support being "A European" and "European Consciousness" after Erasmus.

\section{Experience}

The fact that the Erasmus experience was highly fruitful and beautiful was emphasized by students. No negative opinions were observed in relation to experience. As it may be seen from the student's statements, the Erasmus experience has been referred to with quite positive expressions, such as great, good, wonderful, beautiful, the best, incredible, richest, fantastic, useful, big, intercultural, fruitful, funny etc. A student even said: "Have you ever met somebody who has had a bad experience on the Erasmus program? Stop searching, you will not find it!".

\section{Time}

The most frequently used expression in the time concept was "First time". The students expressed that they lived the advantage of being in a different country and culture for the first time and felt pleased about this.

The concept of time often is used the following attributes; first, great, the best, long, Erasmus, good, free, wonderful, second, hard, The greatest, parties, special, turn back, trip, perfect, short, the craziest, intensive, don't waste, funny, leisure, studing, unforgettable, different, dormitory, memorable, is not lost, the happiest, commercial, marvellous, cool, nice time.

The students evaluated the Erasmus period in a highly positive way. Only two students viewed the period as a difficult time.

\section{New}

The students experienced a lot of new things within the Erasmus process. This is evident from the wide range of the concept "new". The concept of new often is used the following attributes: friends, people, country, cultures, language, experience, life, things, places, world, way, city, me, home, eyes, year, environment, opportunities, family, room, Europeans, EU, knowledge skills, persons, identity, foods, university feelings, style of life, situations staff, prospectives, nationality, projects, challenges, desires, plans, flat, couples, sight, adventure, business, impressions, start ideas, period, view, smells, social rules, self, beginning, landscape, perspective, economy, lessons, generation, revelation, options.

In the light of these attributes we can see how open young people are to innovation and new things. Therefore, we may say that young people are successful in establishing a cross-cultural dialogue.

\section{Different}

The concept of different often is used the following attributes: culture, countries, people, way of life, ways places, language, things, life perspective, parts, 
approach, nationalities, angles, meals, backgrounds, students, companies, origin, university, viewpoints, emotion, conditions, tradition, environment, colours, technologies, reality, games, food, adventure signs, story, eyes, characters, time, accent, motives, programs, spices.

A student even said: "We were so different and so similar at the same time". It is possible to observe that, just like the usage of the concept of new explained above, the concept of different does not convey negativity either and that it has contributed greatly to the lives of the students.

\section{Other}

It can be seen that the word "other" was not used in the sense of otherisation, isolation or discrimination. On the contrary, the students feel excited about getting to know other students, about communicating and interacting with them. As a result, they acquire a European consciousness. The concept of other often is used the following attributes: students, countries, Erasmus students cultures, things, people, places, nation, languages, foreigners, side of life, foreign students, universities, periods, European, food, prejudices, their stuff, habits, perpectives, games, continent, dimension and other colours.

We can observe from the experiences that the Erasmus students have formed friendships with other Erasmus students, rather than the students of the host countries. Erasmus students who leave their homes for a temporary period and share the same environment with other Erasmus students meet in a common ground (in terms of adapting to a new place, acting together, etc.). Therefore, a multi-cultural dialogue comes into the picture. The dialogue between many visiting students ensures cross-cultural interaction and thus contributes to the development of European consciousness and forms integration.

\section{World}

The concept of world often is used the following attributes: a new, real, citizen of the world, marvellous, another, a better, unknown, my little, the world in a village, beautiful, big, a multicultural, fantastic and Erasmus world.

As for the concept "world", the students used it in two senses:

1. The concrete and physical sense: to see new places in the world and discover the variety and colour in the world.

2. The abstract sense: to see different worlds, to explore their own world.

\section{University}

The concept of university often is used the following attributes: host, modern, good, new, different system, guest. Although the main aim and function of the Erasmus program is concerned with university education, the concept of university was not frequently used in the students' experiences. The academic environments, educational system, relationships with the faculty were not mentioned frequently. For instance, the concept of library was used only four times. Usually the university names were mentioned. 


\section{Language}

The concept of language often is used the following attributes: new, different, another, foreign, Erasmus, native, interesting, same, beatiful, body, nicely melodic, Local, very romantic, our own, second, odd and Universal language.

The process of learning a new language was frequently mentioned. The emphasis was on communication despite speaking different languages by making use of body language where possible and even creating a new Erasmus language. "Erasmus language": is not English, Spanish or French... It is the best way to understand the sense of living without speaking, just acting. They said that; "we discovered sign language and body language!"

It has also been observed that the students are highly willing to learn other languages. The students state that they spend an effort to learn other languages even after they go back to their own countries.

\section{DISCUSSION}

This study shows that, during the experience process, the students are happy about discovering a new "me", a new place, new culture and new tastes and making new friends and living the European spirit. The results of the study show parallels with the results of other studies conducted in this area. According to the results of a study by Renata Figlewicz and James Williams: "ERASMUS students in both countries have remained satisfied or very satisfied with their experiences in their host institutions over the course of the last few years. The ERASMUS year is viewed by those that participate as a worthwhile activity" (2005). Various evaluation studies have shown that almost all participating students are highly satisfied with the ERASMUS experience in another European country (Rivza \& Teichler 2007, 67).

Although students go through various problems such as settling into a new environment, adapting, economic, and bureaucratic and language related efforts as expected, the study shows that the students almost never mentioned these problems. Therefore, it may be concluded that living the exciting sides of the Erasmus program (exploring new things) is much more important than the problems they experience. "The ERASMUS scheme for the mobility of students is generally viewed as a "success story". Even though bureaucratic procedures of the programme were often criticized as excessive and even though the stipends provided for students as a rule cover only part of the additional costs for study abroad, ERASMUS became extraordinarily popular" (Rivza, Teichler 2007, 67).

As Dervin comments on the study saying, "Erasmus experience could be one of the greatest training periods for hypermodernity", another study evaluates it as thus: "From the European decision makers' perspective, mobility represents a form of secondary socialization which relies on the individuals" (Papatsiba 2005, 178). Indeed, it has been observed that the students who have participated in this program have been very social. While this process is marked with exploring new places, culture and tastes, their relationships with their friends is also emphasized. During the program, it has also been observed that the students introduce their own cultures to their friends. Therefore, it may be defined as a second socialization period. 
We see that, the European Consciousness is more developed in students who frequently mention "being together despite the differences", compared to those students who only talk about "being together". Another study shows that, students who become a part of the Erasmus experience have been able to dispose of a majority of their prejudices (Mutlu, Alacahan, Erdil, 2010).

\section{CONCLUSION}

In this study, it is observed that the students talked highly positively about the Erasmus experience. The students described this process as enjoyable and productive. The experiences of the students show that they use less frequently academic concepts (such as, university, science, course, instructor, library, research etc.), compared to those concepts about individual development (such as discovering themselves, new places, different cultures; friendships, living the European spirit, etc.)

It could be argued that the Erasmus experience contributed to students' 'individual development rather than academic development'. Another study confirms this result; according to this other research, a change has been observed in the students' motivation in the past three years. The study shows that, while there is a decrease in their motivation about career planning and academic life, there is an increase in their motivation about meeting a new environment (Report on Erasmus Students' Mobility Academic Year 2005/2006, s.3).

Although Europe and the EU have a common history and culture, Europe has witnessed two world wars, the European countries have fought against each other and Europe has witnessed bipolarity during the time of the cold war. Therefore, due to the wars and conflicts of the past, it is a fact that the European youth have certain prejudices against each other. It is possible to see that the students have left a majority of their prejudices behind through cross-cultural dialogue. The fact that there are almost no conflicting and aggressive expressions shows the fruitfulness of this experience. It is also possible to say that the students have developed a new identity.

We may say that, this individual development in the students helps the construction of a consciousness that is European. It could also be maintained that one of the key purposes of the Erasmus exchange program is to remove prejudices by maintaining student mobility and cross-cultural dialogue and to unite societies under concepts such as European Consciousness and Being European through strengthening interactions between EU member citizens. Data collected in this study present evidence that the Erasmus programme has reached this aim.

\section{BIBLIOGRAPHY}

Altbach P.G., Teichler U. (2001). Internationalization and exchanges in a globalized üniversity, “Journal of Studies in International Education" 5 (25).

Brock C., Tulasiewicz W. (1999), Education in single Europe, Routledge Flamer, London.

Byram M. (2001). Living and Studying Abroad: Research and Practice, Multilingual Matters Limited, Clevedon.

Mutlu S., Alacahan O., Erdil M. (2010). Comparison of the personal and cultural change Taking place between EU Erasmus students and Turkish Erasmus students (within the sample of Adam Mickiewicz University in city of Poznan, Poland), "Eurasian J. Anthropology", 1(1) 
Teichler U. (1999), Internationalization as a challenge for higher education in Europe, "Tertiary Education and Management" 5 (1).

Papatsiba V. (2005). Political and individual rationales of student mobility: a case-study of Erasmus and a French regional scheme for studies abroad, "European Journal of Education", 40 (2).

White M. D. and Marsh E. (2006). Content Analysis: A Flexible Methodology, "Library Trends", Research Methods, 55(1).

\section{NETOGRAPHY}

Rivza B., Teichler U. (2007). The Changing role of student mobility, Main Transformations, Challenges and Emerging Patterns in Higher Education Systems. 5-6 March 2007, Paris, France, http:/ / portal.unesco. org/education/es/files/55030/11974530175ENA_PUB_MARCH_2007_ENG.pdf/ENA_PUB_ MARCH_2007_ENG.pdf, retrieved: 21.03.2012.

Devrin F., The Erasmus experience: halcyon days of hypermodernity?, http://users.utu.fi/freder/general. pdf, retrieved: 21.03.2012.

Huisman J. (2004). Responses to European policies: The impact of the Erasmus programme on national policy-making. Paper to be presented at the annual NIG conference 29 October, Rotterdam, http://repub.eur. $\mathrm{nl} / \mathrm{res} /$ pub/1741/NIG1-02.pdf, retrieved: 21.03.2012.

Figlewicz R. And Williams J. (2005). How satisfied are Erasmus students? Paper presented to the 27 th Annual Eair Forum, 28 to 31 August, Riga, Latvia, http://www0.bcu.ac.uk/crq/presentations/eair2005jamesw.pdf, retrieved: 21.03.2012. 